\title{
O SENTIDO DAS FORMAS EM JORGE DE LIMA
}

Gilberto Mendonça Teles*

No poema 19, de Anunciação e encontro de Mira-Celi, Jorge de Lima escreveu que "Encerramos milhares de geraçбes num pedaço de nervo,/ ou num fragmento qualquer de recordaçбes" e falou a seguir em nome "das geraçбes que sintetizamos". Aí está, a nosso ver, uma dupla motivaçăo para este trabalho, originariamente destinado a estudar as relaçðes do poeta com a sua geração ${ }^{1}$, mas geração de nascimento, aquela que Alceu Amoroso Lima chamou "A Geração de 1893". A primeira motivaçao é no sentido de se obter, nđo a melhor definiçao de geraçao, mas pelo menos uma forma de se perceber o processo das geraçðes, sem se recorrer às famosas teorias de Pinder, de Ortega y Gasset e Julián Marias: e a segunda é para depreender, ainda que um tanto superficialmente, um dos processos fundamentais da produção poética de Jorge de Lima.

Tocado pelo significado de síntese de que fala o poeta, o crítico é levado a admitir que o escritor pertence mesmo a uma geração que é síntese de outras gerações ou que contém em si o espaço cultural em que se cruzam discursos e fragmentos discursivos de outras geraçðes. Assim, o escritor pertence a uma geraçao e nđo a uma data central - biográfica, bibliográfica ou extraliterária -, pertence a uma constelaçao de idéias e de técnicas que repercutem na sua pesonalidade e o levam a agir, se nao em companhia de outros escritores, pelo menos marcado por algum ideal estético ou científico, por uma filosofia de vida e, portanto, por uma ideologia, por uma estilística, enfim, por um sentido superior de linguagem que atua na escolha de seus temas, nas suas formas e nas tećnicas que qualificam a sua obra literária, qualquer que seja o gênero em que ela se manifeste.

A partir desta maneira de ver é que se pode chegar ao entendimento de uma "geraçđo de 1983" no Brasil, uma geração cujos participantes passaram a adolescência entre modelos parnasianos e simbolistas e chegaram ao modernismo impregnados de uma retórica e de um transcendentalismo que os marcariam para sempre, deixando nas suas obras as formas de uma modernidade muito mais autêntica, síntese de outras sínteses, desdobramento de uma tradição e de uma continuidade que ño é a da sim- 
ples repetiçao, mas um modo especial de transformação por dentro da linguagem, renovação mais que inovação, o giro contínuo de um calidoscópio e ño as rupturas violentas das soluçðes vanguardistas.

Em Companheiros de viagem, Alceu Amoroso Lima transcreve um artigo sobre o Pe. Leonel Franca, mencionando de passagem sete escritores nascidos em 1893; Leonel Franca, Mário de Andrade, Ronald de Carvalho, Jorge de Lima, Sobral Pinto, Leonídio Ribeiro e ele próprio, não chegando entretanto a desenvolver nenhuma concepçao de geração, que parece ficar aí em torno da data de nascimento do escritor. Só mais, tarde, nas suas Memorias improvisadas (diálogos com Medeiros Lima), deixa claro o o que entende por geração: "O meu conceito de geração é o mesmo de Francisco Ayala, quando o define como comunidade de espírito, de sensibilidade, de atitudes, de preocupações, de problemas, de traços estilisticos gerais - sem prejuízo do estilo particular e demais notas da personalidade individual de cada um de seus membros". Essa "comunidade de espírito" tem muito a ver com a formulaçao poética de Jorge de Lima, uma vez que é a partir dela que recolhemos e sintetizamos os traços possíveis de uma geraçao, como é também a partir da idéia de síntese e de seleçao que o crítico e o historiador da literatura podem organizar o seu discurso, sem cair naquele caos mencionado por Lévi-Strauss, em $O$ pensamento selvagem.

Dessa relação de nomes que comporem (ou compuseram) a "geração de 1893", cada um ocupando um setor especial da cultura brasileira neste século, os nomes de Jorge de Lima e Alceu Amoros Lima (que se encontram ligados neste simpósio $)^{2}$, se destacam por se ligarem mais afetivamente na vida, trabalhando juntos na antiga Faculdade Nacional de Filosofia e por se ligarem ambos a uma Fé que nao encontra precedentes na história da literatura brasileira. Foram companheiros de trabalho, de literatura e de religiao, mas sobretudo acreditaram no seu talento e souberam, cada um no seu gênero, compreender e louvar o trabalho do outro.

\section{APRESENÇA POÉTICA DE JORGE DE LIMA}

Em artigo sobre a poesia de Carlos Drummond de Andrade, ${ }^{3}$ fizemos alusão à | metáfora do calidoscópio/caleidoscópio divulgada por Todorov a respeito dos estudos de história literária. A produção literária de um escritor ou de uma época é comparada ao jogo óptico do calidoscópio. A matéria poética é a mesma para todos, mas cada um a combina diferentemente ou, na sugestão metafórica, cada escritor gira o calidoscópio segun- 
do seus gostos e possibilidades. As belas formas ño passam portanto de combinaçбes de um ponto de vista e até de uma ideologia, estética ou social. Há um elemento identificador que é a substância da tradição literária; é o lado ño-histórico da literatura, o que nao muda, o que permanece como fundo residual ou como patrimônio cultural. E há por outro lado o elemento diferenciador: o próprio processo de organizaçăo que, sendo novo ou nao sendo da época, nđo rompe definitivamente com o conhecimento da tradição e estabelece condiçбes para o estatuto da originalidade; é o que se transforma, o propriamente histórico. No primeiro elemento, a obra se mantém como elo, como elemento continuador da tradição; no segundo, ela póe ênfase em si mesma, sem contudo desligar-se do permanente.

Mesmo que esta maneira de ver a literatura encontre um e outro adepto no passado, parece que é algo típico do século XX, quando as formas se sobreprem à estética e ao sentido. Tanto os estudiosos como os próprios poetas confirmam este ponto de vista. Chklovski escreve que "O trabalho das escolas literárias consiste muito mais na disposição que na criação das imagens". Pierre Reverdy acha que "O poeta é um caleidoscópio. Entra pouca coisa na infinita diversidade de suas combinaçôes" Um coreógrafo, George Balanchine, declara: "Eu nao invento nem crio. Deus já fez tudo. Nossa tarefa é só escolher”. Drummond nos confessou certa vez que para ele o poeta trabalha sempre a mesma obra, como se houvesse um fundo comum que ele estivesse sempre a escavar. E Jorge de Lima, no canto VII de Invenção de Orfeu, afirma que existe

"um caleidoscópio batismal,
ovo armilar tombado nas laringes,
mar opressor caido dos céus rubros.

Enfim, existe sempre a consciência de uma unidade estética, embora repetida e fragmentada, a que se filia a obra do poeta. A consciência de uma tradiçao retomada e enriquecida por uma nova maneira de organizá-la por força de uma personalidade diferente que a retoma, modifica e a apresenta como coisa nova e nunca vista.

\subsection{Uma Possível Leitura de Conjunto}

Numa bela síntese, Alceu Amoroso Lima diz que a época literária que vai de 1900 a 1922 foi nacionalista e eclética e, portanto, de mistura de concep̧̧ōes fillosóficas, políticas e literárias. Quer dizer, concepções 
extralıterárias, como o positivismo e suas vertentes científicas, como o idealismo cristao e suas práticas católicas, tudo isso influiu consideravelmente na intelectualidade brasileira das duas primeiras décadas deste século. Só que não os separou: velhos e novos se viram diante das mesmas expectativas, assimilando-as a torto e a direito, misturando valores e princípios, preparando sem se dar conta a revolução literária de 1922. Para Alceu Amoroso Lima, essa época, além de ser "um movimento de acentuado nativismo, o trecho que vai entre o Simbolismo e o Modernismo se caracteriza, acima de tudo, por nao poder ser resumido numa escola dominante e, ao contrário, compreender a coexistência de simbolistas, realistas e parnasianos, até mesmo os da geraçao que, em 1920, iriam desencadear o Modernismo. Foi o Pré-Modernismo".

Em termos estritamente de história literária, pode-se dizer que a poética dominante era a do parnasianismo, quer dizer, a concepção de poesia que envolvia a vida literária das grandes cidades, como Rio de Janeiro e São Paulo, e de certo modo se espalhava por todo o país, era a do rigor vernáculo da forma poética de mistura com os atributos mais conhecidos dos parnasianos: arte pela arte, domínio da emoçao, rigor formal, temas greco-latinos e uma filosofia aristocrática da existência. Mas juntamente com esta concepção (esta poética), cuja retórica se vulgarizava através dos modelos de Olavo Bilac, Alberto de Oliveira e Raimundo Corrêa, foram-se insinuando concepçбes novas, desdobradas do parnasianismo, desenvolvendo alguns de seus traços discursivos ou opondo-se a eles de maneira a suscitar novas diç̧бes, tidas como extravagantes e estranhas, como as que se vêem na poesia de Cruz e Souza, Moacyr de Almeida, Augusto dos Anjos, Martins Fontes e na de Manuel Bandeira, Mário de Andrade e Menotti del Picchia anterior à Semana de Arte Moderna.

Em síntese: predominava entre os artistas consagrados e o público que os lia a concepção parnasiana, de tal modo que poética e retórica eram codificadas e descodificadas sem maiores exigências de leitura. Com a intromissao das concep̧̧бes novas, a poética parnasiana se viu abalada, mas a sua retórica resistiu e se propagou com tanta força que a "revolução" modernista só vinte e tantos anos depois começou verdadeiramente a substituí-la no gosto popular. E o curioso é que, mesmo a obra dos grandes modernistas não conseguiu de todo eliminá-la, percebendo em quase todos eles vestígios formais da retórica parnasiana, a qual, passados os anos da propagaçao modernista, começa a reaparecer, mas transformada e já sob a ótica de uma filosofia, nðo mais positivista, existencialista, uma filosofia da linguagem assentada nas conquistas da lingüística e da estilística e beneficiada com a aura poética da modernidade. 
Jorge de Lima e Alceu Amoroso Lima, nascidos em 1893 (ano da publicação de Missal e Broquéis, de Cruz e Souza), assimilam, cada um a seu modo, toda a retórica parnasiana e parnasiano-simbolista, em que o exercrcio retórico começava a ser maior que a própria concepçáo poética. Exercitando-se a retórica, apareciam, por força da originalidade criadora, novas possibilidades de expressão, as quais, com o tempo, puderam ser avaliadas como indícios da nova poética. Estas novas concepçбes, convivendo com a parnasiana e sendo por ela desprezadas, começaram uma reação que vai se prolongar na grande aventura modernista. Jorge de Lima aprendeu a poetar com os parnasianos e simbolistas, sobretudo com Bilac e Cruz e Souza; aprendeu a pensar na ideologia cient ffica dos positivistas (e suas várias sub correntes que impregnaram o pensamento filosófico e científico do início do século XX); e aprendeu a religiao com a família, com os Maristas e, indiretamente, com as festas religiosas de sua terra, festas que vão marcar profundamente o seu imaginário. Tudo isso concorreu para o sentido inicial de sua poesia e para a repetição e aprofundamento desses temas ao longo de toda a sua obra, que é, sob este aspecto, um verdadeiro calidoscópio ou, como num verso de Invenção de Orfeu (VIII, 820):

Memorial vôo de círculos concêntricos
em movimento de ilhar circular;
a memória dilata-se e consome-se,
a frase repercute idades, temas,
tardandorinhas enterradas vivas
e ainda atravessando as mesmas tardes.

É portanto dentro desta visão calidoscópica e em espiral que se faz possível uma classificação de toda a produção poética de Jorge de Lima. Mas classificação no sentido de apreensão do mecanismo de transformaçao de seu discurso poético, tomando-se como limites os anos de 1914 a 1952 , datas do primeiro e do último livro do poeta. Assim, toda a sua obra poética pode ser lida em três movimentos que se completam, um saindo de dentro do outro, desdobrando-se no seguinte, numa transformação interior, por dentro da linguagem, isto é, sem recursos extraliterários e com a simples exploração das potencialidades criativas do idioma. Essa variabilidade de uma fase a outra comprova-se na seleção de elementos reiterativos ligados aos temas, às formas (retóricas) e à técnicas de construção do poema e até do livro de poemas. Temos assim ${ }^{4}$ :

a - Fase de Formaçao, dos primeiros poemas até 1932, compreendendo os Sonetos (publicados esparsamente nos jornais antes da estréia em livro), os XIV alexandrinos (1914), os Poemas (1927, que marcam sua ade- 
são ao modernismo), Novos poemas (1929) e Poemas escolhidos (1932). Deve-se acrescentar aí o Poemas negros, de 1947, mas com marcas estilísticas desta primeira fase.

b - Fase de Transformação - a linha religiosa e bíblica, que se manifestava esporadicamente na fase de formação, ganha relevo e, com os recursos da liberdade de expressao modernista, desenvolve uma transformaçao retórica que tem como ponto principal o aprimoramento do verso livre e o uso indisciplinado e meio-surrealista da expressao metafórica. Compreende os livros Tempo e eternidade (1935, em colaboraçao com Murilo Mendes), A túnica inconsútil (1938), Anunciação e encontro de Mira-Celi (1943) e Livro de sonetos (1949).

c - Fase de Confirmaçăo, dando-se à pálavra confirmação o sentido latino da confirmatio, isto é, do que se confirma, do que se consolida, afirmaçao que se confirma e se supera. Compreende a fase do poema épico-lírico Invenção de Orfeu, de 1952, um ano antes da morte do poeta, mas cuja concepção data de dez anos antes. Esta fase é ao mesmo tempo a soma de todo o saber poético e retórico de Jorge de Lima e, também, de toda a poesia brasileira.

É preciso que se entenda o sentido dialético no interior de cada fase e de uma em relaçao à outra, se nđo num movimento incessante, pelo menos num dinamismo de transformaçao na direçao do mais puro, do mais belo e até do mais culturamente necessário. Isto nao quer dizer que o poeta consiga sempre uma gradaçao ascendente. Às vezes o que se queria methor redunda inferior, o que se pensa para frente pode funcionar retrogradamente. Há marchas e contramarchas na história das formas literárias. Mas o que se conta na lógica dialética é que A é sempre A mais alguma coisa. Ser é ultrapassar-se, é negar o seu absoluto, tal como, na esteira de Hegel, escreve Henri Lefebvre explicando o método dialético em relação à lógica formal: "Ao primeiro termo imediato da afirmaçao sucede um segundo, no mesmo plano, que o completa negando-o. Os dois termos agem e reagem um sobre o outro. O terceiro volta ao primeiro negando o segundo, ultrapassando assim um e outro. A unidade do mundo se exprime num princípio de identidade tornada concreta e viva pela sua vitória sobre as contradições" $"$.

\section{A - Fase de Formação}

Cada fase da poesia de Jorge de Lima afirma e nega ao mesmo tempo. Melhor, há um momento de afirmaçao e logo a seguir, à medida em que o poeta adquire os elementos de sua formaçao, a sua poesia passa a outro 
tipo de afirmação que, sem negar totalmente o primeiro, dele se afasta, superando-o e até contradizendo-o. Assim é que, ao publicar os XIV alexandrinos (bem como os vários sonetos esparsos nos jornais), o poeta afirmava o saber de uma retórica parnasiana, privilegiando a forma do soneto, exibindo as suas chaves de prata e de ouro, polindo os seus versos e as suas imagens e esmerando-se num vocabulário muito a gosto dos parnasianos, Bilac sobretudo. Não é coincidência que Jorge de Lima publique quatorze sonetos alexandrinos: é que, no fundo, se trata de uma coroa de sonetos, só que sem o rigor desse tipo de composição de que os poetas da geraçao de 45 vão-se ocupar sem grandes resultados. A dicção bilaqueana coabita os versos do primeiro livro de Jorge de Lima. Um soneto como "Natura mater" dá bem as dimensőes do que falamos, tal como se pode ver, na sua primeira estrofe:

Clorofila e pletora enchem-the o seio farto

E trajam-lho de verde e cobrem-lho de ninhos!

E tão nova, parece, é o seu primeiro parto

Que fez o bosque, o rio, a flor e os passarinhos!

Não só o corte do verso, mas também as palavras caras ao poeta de Tarde: clorofila, pletora, seio, farto, ninhos e a enumeração do último verso.

No entanto, ao longo dessa "coroa de sonetos", a ideologia científica do positivismo, do evolucionismo, também se faz patente, percebendo-se a dialética dos dois discursos que procuram equilibrar-se, como se a retórica de Bilac, manifesta inclusive por uma epígrafe do poeta, dialogasse com todo o estranhamento dos temas e do vocabulário de Augusto dos Anjos, cujo livro $E u$ foi publicado dois anos antes dos XIV alexandrinos. Aliás, uma boa maneira de comprovar o dialoguismo desses dois discursos é ler mais verticalmente os sonetos que abrem e fecham a série, dado o tom metalingüístico que os envolve, deixando-se perceber, ao mesmo tempo, o choque das duas concepçбes poéticas e o estranho conúbio das duas retóricas: a parnasiana - aberta ao realismo científico; e a simbolista - aberta à emoçao de um imaginário ainda meio tolhido na sua manifestação. No primeiro, expбe a sua opiniðo a respeito da discussão da morte da poesia em face da ciência e se coloca numa atitude conciliatória, escrevendo:

Se mesmo o positivo é sonho e controvérsia Nem Porvir, nem ninguém, cousa alguma desliga A Ciência que sonha e o verso que investiga.

O poeta fala da Química, da Mecânica, da Astronomia, da Ciência, do Por- 
vir, assim, com letra maiúscula; fala no positivo; mas, no verso final, mistura a Ciência e a Retórica, melhor, leva a investigaçao científica ao terreno da poesia, ño só antecipando os grandes estudos de Poética e Retórica da atualidade, como levando o imaginário ao terreno da Ciência, numa antecipação também das atuais especulaçбes psicanalíticas. Toda essa agitação ideológica confluirá para o último soneto, que tem por título "Paixão e Arte", notando-se logo à primeira vista a inversáo dos termos da paixão à arte, entendendo-se esta no seu sentido etimológico, nao do latim ars, artis, mas do grego aretê, predicado essencial da téchne, base do espírito científico. Vejam-se o primeiro quarteto e o último terceto desse poema:

Ter Arte é ter Paixão. Não há Paixão sem verso...

O Verso é a Arte do Verbo - o ritmo do som...

Existe em toda a parte, ao léu da Vida, asperso

E a Música o modula em gradaçб̄es de tom...

Homem, faze do Verso o teu culto pagao

E canta a tua Dor e talha o alexandrino

A quem te acostumou a ter Arte e Paixão.

O sentido emocional aparece em primeiro plano, no título; e só depois, ao iniciar o poema, já percebido como obra de arte, é que o lado artístico, vale dizer, o saber da coisa estética assume o primeiro lugar na frase curta e tão racional que rompe a unidade do verso inicial do soneto: "Ter Arte é ter Paixão". Atitude que depois de se referir diretamente a Paixao de Cristo e conotar portanto elementos catárticos e simbólicos da criaçđo, o poeta mantém até o verso final, quando o sintagma "Arte e Paixão" estabelece um belo quiasmo com o título, mostrando por isso mesmo os dois elementos concomitantes da criação poética (a intuição e a reflexão) e até mesmo sugerindo as duas vertentes da poesia na modernidade: a que vem das forças obscuras do incosciente e aquela racionalmente conquistada.

Aliás, ño é por acaso que numa de suas entrevistas (1945) alude ao apólogo de Claudel, sobre Animus e Anima, em que Animus "simboliza a inteligência, a consciência, a vontade"; e Anima, "a intuiçao, a sensibilidade, o subconsciente". Na narrativa de Claudel, a esposa, Anima, só consegue cantar longe do marido Animus, donde a conclusão - apressada - tanto de Claudel como de Jorge de Lima de "que todas as vezes que a inteligência, a consciência, a vontade intervêm no mistério leigo da poesia, este não se produz. A preocupação de contar sílabas, escolher rimas, enfeitar o verso, faz com que Anima ño cante...". É que o poeta confunde aí duas coisas: a poesia, enquanto abstração; e a obra literária, o poema, o livro de poema, enquanto realidade concreta. Além do que, a nđo ser numa narrati- 
va desse tipo, intuição e reflexão não se encontram assim tão "divorciadas" e, como ensinam hoje os estudos psicanalíticos da linguagem, muita coisa que parece clara realização da consciência não passa, no fundo, de obscuras manifestações do subconsciente; o que parece fala nao passa de algo falado por uma ideologia que interfere em todas as nossas atividades culturais.

Estas duas atitudes antitéticas conseguem entretanto um equilíbrio provisório nessa fase de formaçðo, quando o poeta na verdade mais assimila do que cria: o que ele pensa estar criando só corresponde a uma parte do que ele verdadeiramente cria; mas é justamente esse equilíbrio que constitui uma das muitas modalidades do ecletismo de que fala Alceu Amoroso Lima. Temas, formas e técnicas, rastreados nos seus poemas iniciais ou nos poemas até a sua adesão ao modernismo, em 1925, mostram bem essa mistura de elementos parnasianos, simbolistas, cientificistas e religiosos. O tema da arte e religiao, por exemplo, aparece num soneto de 1908, "A morte do artista", cujo terceto final é:

Nossa Senhora soluçando estava...

Tanto chorara por Jesus outrora,

Quanto chorava pelo novo filho!

As formas métricas e poemáticas do soneto, se revelam mais o corte parnasiano, não escondem termos e ritmos simbolistas e cientificistas, como noutro terceto final, desta vez de um soneto denominado "Meu descassílabo", onde é fácil perceber a influência de Augusto dos Anjos:

\section{- herdeiro dos pavores do Selvagem \\ e dos vícios, das dores, das desgraças \\ originárias de milhð̋es de raças...}

E, claro, para trabalhar esses temas e essas formas, a técnica, o instrumento artístico do poeta se foi também afinando, adquirindo um desempenho pessoal que o seu talento conduzia entre as várias influências no sentido de sua própria originalidade. Fez sonetos, tal como o fizeram parnasianos e simbolistas, mas alguma coisa nova se vai insinuando no seus sonetos: a maneira de jogar com os ritmos e as pausas, o olhar medroso sobre o seu próprio instrumento de trabalho, a seleção de aspectos de sua vida regional e provinciana, como no célebre "O acendedor de lampiōes". Mas quando já estava ficando senhor de sua arte sucede-lhe o engajamento no modernismo, iniciando-se nova aprendizagem e criando-se uma concepçao de poesia que, pelo menos programaticamente, constitufa oposição à concepção originária. 
Foi com o livro Poemas, de 1927, mas com textos desde 1925, que Jorge de Lima iniciou a sua grande aventura modernista. $\mathrm{O}$ saber literário acumulado levou-o a uma situação de comedimento diante da nova retórica que ele ia também assimilando neste seu período final de formação. $O$ passado atuava na seleçao dos temas, das formas e das técnicas modernistas. Os temas. se largam agora na recuperação das cenas da infância, no sentimento nacionalista e até pan-americano e, principalmente, na poetização dos elementos do folclore negro. É com Jorge de Lima que o negro se torna tema não do|aristocrático modernismo paulista, mas de grupos que aparecerão e editarão jornais com o nome de Leite criôlo, tal como se deu em Belo Horizonte. As formas se despem de seu tradicionalismo, se tornam novas, a fim de expressarem mais espontaneamente os novos temas. Começa, pois, a disciplinaçao do verso livre; desaparece por completo o soneto; as imagens se tornam mais vigorosas e adquirem grande originalidade. Quanto a técnica, que está na adequação eficaz de temas e formas, ela se nota mais vivamente no processo da intertextualidade: o poeta começa a inserir no seu discurso traços discursivos de outros poetas. Inicialmente, ele os aponta, pondo-os em itálico ou entre aspas; mais tarde esses traços vão se fundindo e se confundindo na profundidade da sua poesia. É o que acontecerá, com toda a sua plenitude, em Invençđo de Orfeu.

Não é gratuita a comparação do seu primeiro poema modernista, "O mundo do menino impossível", com o seu último livro, Invenção de Orfeu: o processo de um continua e se aperfeiçoa admiravelmente no outro que é, afinal, a grande síntese, ño apenas dos temas, formas e técnicas, mas uma espécie de soma de toda a sua poesia e, num plano superior, uma das grandes sumas da poesia em língua portuguesa. 0 sentido da intextextualização se aproxima inicialmente das collages cubistas, com frases em francês, inglês e espanhol e, mais fundamente, com a incorporação do discurso narrativo e de formas simples do folclore luso-brasileiro. Todo esse procedimento cresce de poema para poema na sua grande afirmação da modernidade. Começam a aparecer no texto os nomes de poetas (Garcilaso, Whitman), aspectos religiosos e regionais, paráfrases, fórmulas de encantamento, crítica aos parnasianos ("bigodes parnasianos"), à gramática e à retórica ("os adjetivos rubinundos"), mas a grande técnica modernista desenvolvida por Jorge de Lima será a da intertextualização ou da montagem, como lhe chama Luiz Busatto. ${ }^{6}$ De repente, tudo passa a fazer parte da poesia de Jorge de Lima; fragmentos, citaçбes, paráfrases, periffrases, paródias, alusões, enfim, todas as formas de discurso paralelo aparecem nos seus poemas, como se o poeta quizesse atualizar neles toda a sua experiência de vida cultural. Muitas dessas "citações" vão ser retomadas em Invenção de Orfeu, como, por exemplo, a preocupação da etimologia do 
rio Mundaú que aparece no poema "Caminhos de minha terra", de Poemas, e no canto VIII de Invenção de Orfeu.

As oraçбes, como Ave-Maria, Pai Nosso, Salve Rainha, além de outras, sao comuns na poesia dessa fase, como se pode ver no fim do "Painel de Nuno Gonçalves", quando descreve o português, "palitos nos dentes, cebolas e alhos, / tamancos nos pés, / tamancos à vela boiando no mar:

boiando,

levando

o painel,

com ele forrando um leito macio,

de onde três raças, trếs magos

suspirando,

gemendo

e chorando,

olham um gigante deitado,

dormindo, sonhando,

sob uma cruz de estrelas,

encantado.

Expressø̃es gerundiais da "Salve, Rainha" sao metidas no texto, criando com ele oposições entre o sério e o jocoso, entre o sagrado e o profano.

O belo poema "Rio de São Francisco" é também um espaço onde se encontram todo tipo de rererência ao Nordeste, tema que Jorge de Lima aprofundará em Novos poemas, 1929, e sobretudo em Poemas escolhidos, cujo poema inicial se chama exatamente "Nordeste" e onde também se cruzam várias referências culturais, inclusive a do sebastianismo. O êxito de "Essa Negra Fulô" (de Novos poemas) levou o poeta a aprofundar o tena do negro, reunido poemas que só em 1947 publicou com o título de Poemas negros. Temas, formas e técnicas desse livro apontam para a fase modernista do poeta, mas já se vão também mostrando na direção de outra sarda, como se o poeta, inconformado com o expressionismo da dicção modernista, fosse lentamente experimentando outra maneira de dizer os seus temas favoritos.

Um poema como "Sđo Cristóvao Colombo", de Poemas, constitui o grande exemplo de como, no período modernista, Jorge de Lima atualizava o seu pensamento poético, lançando mđo de paráfrases históricas, misturando os gêneros, utilizando um verso livre muito próximo da prosa e, através de ligeira alegorização, dando caráter nacional e presentificação ao processo religioso. A sua ânsia de coloquialismo é tão grande que, nos dois últimos versos do poema, retira ao leitor toda uma carga de sugestão que a própria 
dinâmica do poema vem motivando. Apesar de sua beleza, o poema peca por demasia:

- Me passa no mar, S. Cristóvão! Me passa, eu quero passar pra lá. -

E S. Cristóvao Colombo passou Jesus pra cá. O menino queria novos rios.

E quando os missionários, os bandeirantes, os descobridores passavam os rios, Jesus passava também.

Jesus viu rios, pororocas subindo contra os rios, rios inventando caminhos, rios de peixe de choque, rios e rios passando a terra pra o mar.

Os descobridores passavam o rio, passavam Jesus também, Faziam uma capelinha, deixavam Jesus na margem.

$\mathrm{O}$ menino era pequeno mas pesava, pesava mais que todos os homens juntos.

Diziam: Jesus ficou na beira do rio, trancado, na capelinha. E quando topavam outro rio, sempre uma vozinha: - Me passa pra lá. Me passa!

Meu S. Cristóvão é você, S. Cristóvao Colombo que passou Jesus no mar.

Meu S. Cristóvão é você, S. Cristóvao Colombo que passou Jesus pra cá.

Pelo que se viu, a fase inicial, de Formação, compreende dois momentos na poesia de Jorge de Lima: o de assimilaçao da retórica parnasiano-simbolista e o de superação dessa retórica no sentido da iniciação modernista. Cada momento, por sua vez, é marcado por uma contradiçđo interna em que a primeira afirmação cria condiçoes para a sua própria negaçao, motivando assim a segunda afirmação e, ao mesmo tempo, uma situação de síntese, de saída para outro processo de afirmação, mas já noutra etapa do desenvolvimento.

\section{B - Fase de Transformação}

Esta fase marca o pleno amadurecimento do poeta que entra agora nos seus quarenta anos e dispore de uma sólida e reconhecida experiência das técnicas poéticas e retóricas do passado e do modernismo que ele ajudou a consolidar no Nordeste. Mas, ainda que excelente poeta modernista, a ponto 
de alargar e desenvolver os temas e as formas da poesia moderna, Jorge de Lima continuava a sua busca de originalidade, como se a exteriorização expressionista, o descritivismo e a referencialização posta em voga por futuristas, cubistas, dadaístas e "espiritonovistas"7 - de resto a grande síntese de que vai partir o modernismo brasileiro - nao tocassem o poeta no mais recôndito de sua alma, como se tudo isso só the trouxesse alguns prazeres estéticos, sem interessar fundamente o seu espírito, cada vez mais impregnado de problemas religiosos e metafísicos, a que as especulaçбes surrealistas vieram trazer novas possibilidades de pesquisa poética.

Assim, a poesia produzida nesta fase inicial vai ser a radicalizaçåo de uma religiosidade que, presente na fase inicial e primariamente assimilada das tradições familiares e do folclore de sua terra, passam a exigir agora um aprofundamento filosófico que encontrou na retórica modernista os elementos expressionais de que necessitava. A liberdade de experimentaçao estética foi aliás o signo desta nova afirmação, em que os temas regionais e americanos, os motivos negros e sociais da década de vinte e a grande experiência na produção de uma linguagem poética, quevariou do sublime ao mais ingênuo coloquialismo, encontraram uma personalidade literária admiravelmente preparada para extrair daí a sua mais autêntica originalidade.

A partir de Tempo e eternidade, publicado em 1935 juntamente com Murilo Mendes, Jorge de Lima se engaja em cheio no tema do catolicismo, explorando-o através dos textos bíblicos, da mitologia cristã e de uma imaginação pessoal em que se incluem, como se disse, a formação religiosa familiar e, no fundo, o fastígio folclórico em torno das novenas e festas de uma regiao mais rica em tradiçðes populares no Brasil, que é Alagoas. Logo no primeiro poema desse livro, poema sintomaticamente denominado "Distribuição da poesia", já aparecem os sinais da nova concepção poética que vai, daí para a frente, ganhar dimensøes surpreendentes na sua criação literária. Aparece aí, pela primeira vez, a palavra ilha (a referência à paradisíaca Ilha de São Brandão, metáfora indireta da Ilha de Santa Cruz); e lê-se a universalização de sua nova concepção, quando escreve: "poesia tirei de tudo / para oferecer ao Senhor". A ilha passa a ser vista como o paraíso perdido, próximo de Deus e, portanto, próximo das origens. Esta visão vai cada vez mais crescer, de livro a livro, até tornar-se o tema central e majestoso de Invenção de Orfeu. Aliás, os livros desta fase podem ser lidos como preparatórios, como ensaios na direção da sua grande obra final.

O poeta está agora sob o signo do sagrado e as suas referências imediatas são primeiramente para Deus, Cristo e personagens bíblicas; e a própria linguagem é dádiva divina: 


\section{Aceito as grandes palavras eficazes}

e os caminhos que Deus pôs diante de mim.

E isto está praticamente em todos os poemas de Tempo e eternidade e chega ser redundante, de uma beleza redundante, como em "As grandes horas e a antiga vigília": "A multidão era imensa / e a voz começou a dizer / que não podia falar na primeira pessoa, / que os poetas eram inumeros na terra. E todos se entreolharam e viram que eram poetas. / Todos tinham sido humilhados, todos tinham sido roubados, todos tinham setas no lado esquerdo do corpo. / E ja era de tarde e todos aqueles poetas cantaram / as Vésperas do Senhor. /

$\mathrm{E}$ a noite chegou e todos aqueles poetas ficaram acordados escutando as grandes horas e esperando na antiga vigília.

E o galo cantou: e milhøes e milhøes de sirenas de fábricas cantaram matinas. E o dia acordou. E todos aqueles poetas viram o Dia subir. E subiram com o Dia.

E cantaram Laudes ao Senhor.

Dir-se-ia que Jorge de Lima escreveu esse livro com a Bíblia de lado, tantas são as referências e alusões a temas e passagens do Antigo e do Novo Testamentos, a ponto de penetrarem na sua linguagem e na forma retórica de seu poema, com versos livres que se aproximam dos versículos, como em "Convite de Salomão" ("A pressa-te, amiga minha, querida minha e vem olhar a manhă."), técnicas que serão ampliadas no livro seguinte, $A$ tünica inconsútil, de 1938.

Comentando A túnica inconsútil, Mário de Andrade escreveu que há um certo academismo na poesia de Jorge de Lima, acrescentando que o poeta nao o despreza "nem fez dele esse bicho-papao que tem sido a maior desgraça, a causa de maior enfraquecimento da manifestaçao artística contemporânea". E diz mais: "É deste academismo, desta obediência altiva ao cânone, que a obra toda de Jorge de Lima beneficia. No momento, ela será talvez a poesia mais clássica do Brasil contemporâneo". $\mathrm{A}$ acuidade crítica de Mário de Andrade nao é de admirar; como homem ligado a todas as atividades culturais brasileiras, ele sabia ver mais que os próprios críticos. O legado parnasiano-simbolista, temperado com a liberdade expressiva do modernismo e nimbada pelo talento do poeta na sua maturidade, fazia da poesia de Jorge de Lima um modelo de linguagem sóbria, elegante e aristo- 
crática sem ser pedante ou ostensivamente da moda. $O$ poema inicial desse livro, "Poema do Cristao", por onde se vê que a temática crista continua o seu aperfeiçoamento, está todo respigado de índices de uma compreensão poética universal e, neste sentido, clássica. Alí se lê:

\section{Porque o sangue de Cristo jorrou sobre os meus olhos, a minha vis̃̃o é universal.}

E aparecem expressర̃es como: "Sou ubiquo: estou em Deus e na matéria", "compreendo todas as linguas, todos os gestos, todos os signos" e "Sou inconsútil como a Sua túnica, / sou numeroso como a sua Igreja". E se lêem também a continuidade e a evolução dos temas, formas e técnicas na sua gradação no rumo de uma perfeição artística jamais desprezada. A sua poesia é, nesta fase, uma espécie de linguagem para a comunhðo com as esferas do sagrado; é uma poesia cheia de anjos, metáforas etimológicas dessa comunicação. O mar, as ilhas, as viagens, os descobrimentos, enfim, todos os motivos de Invenção de Orfeu estao aí, em potência, levemente conjugados. No meio dos versos livres, cada vez mais largos na direção dos famosos poemas-em-prosa, surgem, como uma ilha, os poemas metrificados, como o "Convite para a ilha", cujos versos finais dao bem a amostra de como a contenção do metro antigo cedeu lugar a um tipo de verso que, embora metrificado, é comandado pelo ritmo de duas redondilhas menores justapostas, num agradável embalo musical:

\footnotetext{
Meninas, partamos que as noites de escuro ño tardam a chegar. Entao que é da ilha, da ilha mais bela que há pelo mar e onde se pode sonhar com os amores que nunca na vida nos hão de chegar?
}

O último poema de $A$ túnica inconsútil é a "Ode da comunhão dos santos", dedicada a Alceu Amoroso Lima. Ê um texto poético, e bíblico, mas em prosa, com um poema intercalado e com alguns versos em latim da "Ladainha de Nossa Senhora". O poeta mistura religiao e ocultismo, além de referências a numerologia. E passa, a partir daí, ao ponto maior de sua travessia poético-religiosa, na direçao das experiências com o verso livre, com o refinamento de sua temática e com o pleno domínio de sua técnica poética.

O livro Anunciação e encontro de Mira-Celi, de 1943, constitui o extremo da nova tese poética de Jorge de Lima, o momento em que a sua 
criação, de tão tensa na sua nova afirmação, superava todas as experiências do modernismo brasileiro, misturando os gêneros (ou pelo menos os poemas em prosa com os poemas em verso), abolindo os títulos e numerando os poemas de 1 a 59 e dando a seu livro uma unidade que ultrapassava a simples unidade poemática, atingindo a unidade-livro, numa evidente preparação para a unidade que alcançará com Invenção de Orfeu.

Os poemas de 1 e 59 abrem e fecham estruturalmente o livro. O primeiro começa assim: " $O$ inesperado ser começou a desenrolar as suas faixas em que estava escrita a história da criação passada e futura. / Retirou a sua imensa cabeça de dentro da torre, sob o estrondo das muralhas desabadas com seu gesto". E o último, depois de repetir as duas linhas iniciais, acrescenta: "Continuava incluso na eternidade; por isso podia ver-se dentro da morte, como dentro da vida. / Reencontrou-se amiúde com todos os amigos e amigas que cruzaram a sua órbita. / Amou Mira-Celi como o último segredo do absoluto ou a chama ignea mais intima da Substancia". Tanto o primeiro como o último termina com transcriçōes de textos latinos. Esta abertura e este fechamento mostram o domínio da arte do poeta e contêm, em potência, as especulações metafísicas e poéticas a respeito do nome da musa, Mira-Celi, Maria do Céu, Nossa Senhora, Musa, enfim, como se lê no poema 2: "Tu és, ó Mira-Celi, a repercutida e o laitmotivo que aparece ao longo de meu poema". Neste mesmo texto dirá: "Pouca gente encontrará a chave deste mistério" e "Dei-te diversos nomes, para que ninguém te acompanhe. / Quase sempre te transformo, para te distribuir". E, concluindo:
Algum sacerdote antigo já nos tinha visto, por acaso, uma noite e morreu sem nos decifrar, pois nao voltamos ainda nem à primeira página, nem à primeira estrofe do imenso e misterioso poema sempre por terminar.

Este livro está mesmo no vértice de uma evoluçao poética: seus temas continuam temas anteriores juntamente com índices que serão desenvolvidos nos dois últimos livros do poeta. Surgem afirmações metalingüísticas enfáticas, como no número 4 ("Os grandes poemas ainda permanecem inéditos"), no número 27 ("O nome afinal que importa d essência de um poema?"), no número 37 ("A órbita de Mira-Celi é imensa / e nela ainda há consolos que nunca foram ditos / a falta de palavras na linguagem dos homens") e no 56 ("Os grandes poemas começam com a nossa visão desdobrada"). E começa a ganhar relevo as referências à obra de Camøes, como se pode ver em diversas passagens, sobretudo no poema 16 onde se fala "dos barões assinalados". A cabala e a numerologia são várias vezes aciona- 
das, como sintomaticamente no número 13 e no 58 , números cuja soma é também 13. Agora, do ponto de vista da numerologia, o curioso é que este livro tem 59 poemas e foi escrito quando o poeta fez cinqüenta anos. Por que nao teria arredondado o número, escrevendo 60 poemas? Será que, preocupado com números, ele temia o 60 , idade com que iria morrer? Ou será que o número 60 estaria reservado para a unidade geral do livro, cujo título diz da anunciação e do encontro da grande musa final, que nada impede seja lida também como a morte.

Tal como se deu na Fase de Formaçao, que compreende a iniciação parnasiano-simbolista e, logo a seguir, a iniciação modernista, uma se opondo dialeticamente à outra, a Fase de Transformação também possui internamente a sua dialética: de um lado, os livros até agora mencionados e que levaram à perfeição certos aspectos da sua concepçao poética, afirmando a evolução de uma linha discursiva; e, de outro, opondo-se inteiramente a esses livros, a obra intitulada Livro de sonetos, publicada em 1949, quando Jorge de Lima já trabalhava Invençao de Orfeu. À liberdade expressiva e formal dos livros anteriores, o poeta opøe agora o exercício rigoroso do soneto, de um sistema formal tradicional que retoma o primeiro livro, de 1914, só que aqui noutras dimensðes de linguagem e, em relação ao próprio soneto, numa certa orgia criadora, com versos parecidos com os do simbolista Cruz e Souza e com repetiçoes dentro do próprio livro, retomando e desenvolvendo temas de sonetos anteriores, com uma preocupaçao metalingüística em crescendo e com toda a indicaçao de que se preparava para o máximo de sua inventividade.

O Livro de soneto é assim, nao só a negaçao dos livros imediatamente anteriores, na Fase de Transformaçao, como é também uma síntese temática desses livros, quer dizer, ele opøe-se formal e tecnicamente a livros como Tempo e eternidade, A túnica inconsútil e Mira-Celi, mas os continua tematicamente, em forma de soneto, em forma de filtro formal por onde deveria passar a essência do grande poema que concomitantemente escrevia, tanto que existem sonetos inclurdos nos cantos de Invençâo de Orfeu. Para dar apenas uma mostra desse momento antitético da sua poesia, veja-se o décimo sete soneto, em que a reflexđo sobre a linguagem poética acaba se inscrevendo no discurso do sagrado:

Não procureis qualquer nexo naquilo que os poetas pronunciam acordados, pois eles vivem no âmbito intranqüilo em que se agitam seres ignorados.

No meio de desertos habitados 
só eles é que entendem o sigilo

dos que no mundo vivem sem asilo parecendo com eles renegados.

Eles possuem, porém, milhøes de antenas distribuídas por todos os seus poros aonde aportam do mundo suas penas.

São os que gritam quando tudo cala, sao os que vibram de si estranhos coros para a fala de Deus que é a sua fala.

\section{C - Fase de Confirmação}

Depois de notáveis experiências na poesia do modernismo, como obras que marcaram os anos que se seguiram a 1930, Jorge de Lima publicou em 1952 a sua Invençăo de Orfeu, que tem como subtítulo: "ou Biografia Épica, Biografia Total e não uma simples descrição de viagem ou de aventura. Biografia com sondagens; relativo, absoluto e uno. Mesmo o maior canto é denominado - Biografia". 9 O livro divide-se em dez cantos, mas os poemas já não são intitulados, como nos de Cassiano Ricardo. Os capítulos é que possuem títulos, como Fundação da Ilha, Subsolo e Supersolo, Poemas Relativos, As Apariçбes, Poemas da Vicissitude, Canto da Desaparição, Audição de Orfeu, Biografia, Permanência de Inês, Missão e Promissão. E o mais surpreendente e o mais difícil e talvez o mais belo livro da poesia brasileira, o livro que atualiza a nossa lírica no plano universal dos grandes poetas europeus. Ê a nossa epopéia lírica, em que, evidentemente, as palavras epopéia e lírica se completam para a expressao de uma nova idéia, de um gênero superior ainda ño denominado, tal como já havia tentado obter, em nível pan-americano, Joaquim de Sousa Andrade (Sousândrade). ${ }^{10}$

Todos os planos da nossa realidade cultural - européia e sul-americana - aparecem em Invenção de Orfeu numa simbiose altamente criadora, em que os mitos se entrelaçam com as impressøes de leitura, com os traços da cuitura luso-brasieira, com a metafısıca, com a poética, enfim, um texto em que mitos, simbolos e signos, num iogo entre o real e o irreal, remetem para uma realıdade maior, que é a do próprio texto, com o seu sistema semântico, com a sua poesia. Daŕ a pergunta de Jođ̃o Gaspar Simðes, na "Nota preliminar" que saiu como prefácio: "Como reagirá a crítıca brasileira se eu disser que a Invençâo de Orfeu é o primeiro poema da brasilidade?" Como se vê, pelo longo subtítulo, trata-se de um livro hermético, no mais puro sentido poético de hermetismo. Nao é à-toa que a melhor críti- 
ca o tem aproximado da obra de Camões, de Góngora, de Lautréamont, de Rimbaud, de Mallarmé, de Dante e de Virgílio e a de místicos como Blake. Com esse poema, Jorge de Lima lança pela primeira vez na poesia brasileira as bases de um grande poema metalingüístico, pois nesse livro tudo concorre para a celebração do poema em si: o poeta conquista uma ilha (a ilha dos Amores, de Camores, que é ao mesmo tempo a Ilha de Vera Cruz e, também, a redução de todas as utópicas e fabulosas ilhas da Idade Média e do Renascimento, lugar paradisíaco, útero e morte), e sabe que tem de viver nela para sempre, por isso inventa também um companheiro, Orfeu, que é, por sua vez, o inventor da Poesia. É portanto a poesia sobre a poesia, a linguagem sobre a linguagem - metalinguagem. Ou, na terminologia de Julia Kristeva, um excelente exemplo de intertextualidade na poesia brasileira, um dos maiores em toda a língua portuguesa.

Há no poema de Jorge de Lima uma evidente analogia estrutural com os primeiros capítulos do Gênese, como há também alusão à Illha dos Amores, do canto de Os Lusiadas. No feixe de informaçøes ou de material poético em Invenção de Orfeu, o que realmente mais se destaca é o da ascendência camoniana. Jorge de Lima trabalhou consientemente sobre o modelo épico de Camøes. São claras as referências a temas, a palavras, frases, imagens e versos de $O s$ Lusíadas, a começar pelo primeiro verso do poema jorgiano: "Um barão assinalado", que já aparecia em Mira-Celi.Uma simples leitura colhe referências a "tormentório Cabo", a "flautas rudes", "Tétis", "Adamastor" (inúmeras vezes), a "cabos-nđo", "El-Rei”, "Indias”, "oriente" e "ocidente", "Taprobana", "Ganges", "Restelo", "Inês de Castro", "Cítia fria", "Líbia ardente". "Camōes meu bardo" e tantas e tantas outras, diretas ou indiretas, estilísticas e estruturais. Há versos inteiros de Camøes (devidamente grifados, o que é curioso, quando se sabe hoje, graças ao trabalho de Luiz Busatto, que o poeta se apropriava constantemente de textos dos outros), como no poema XXXVIII do Canto Primeiro.

\section{A soberba Veneza está no meio}

das aguas - que táo baixa comę̧ou!,

versos tirados da estância 14 do canto III de Os Lusíadas. No Canto Segundo de Invenção de Orfeu, o poema IX começa com a seguinte estrofe:

O Memória dos mares, Taprobana, sou da raça de nautas submergida.

E este monstro! Que monstro tão antigo!

Tão puro Adamastor, tão reversivo, Tão grosso deus, tđo pura geografia!

Não quero exatidões nem astrolábios. 
Ontem se arou a terra, replantou-se

a progênie dos seres indivisos.

Como se disse, a "epopéia" de Jorge de Lima é ao mesmo tempo épica e lírica ou, convincentemente, epicolírica ou epilirica, alguma coisa assim, diferente, mistura de gêneros, tal como fizeram Sousândrade e Cassiano Ricardo, a ficarmos apenas na esfera camoniana do Brasil. Murilo Mendes, em artigo publicado em $A$ Manha, de 10 de junho de 1952, dia da morte de Camós, chama o livro de Jorge de Lima de "poema-rio", "monumento barroco", "afresco" e acrescenta: "Por aí se terá uma idéia do poderoso conteúdo e complexidade do livro, que manifesta variadas influências da arquitetura, da pintura, da música, da história, da mitologia, da teologia". Assim, em Invenção de Orfeu, o leitor ño sabe até onde vai o épico ou de onde vem o lírico, pois o que se vai contar agora é que se trata de um texto poético, onde se cruzam reminiscências da epopéia e da lírica de Camóes, como também de outros poetas "assinalados". O que se tem, portanto, é uma dupla linguagem: a do poema e a da poesia, ou seja, um novo discurso poético, com o seu enunciado - o texto incrustado no contexto retórico brasileiro; e o seu processo de enunciação - a linguagem se mostrando poeticamente no seu momento de criaçao, como se pode ver numa das últimas estrofes do poema:

Estilhas de linguagem acendidas,
insônias repousantes, lanhos doces,
verdades sem pensar, pronúncias livres,
a frase além dos lábios, jogos lépidos,
no cerne a louquidão sempre almejada,
os leves manuais discricionários,
os cortejos passando novamente,
os nomes de outra vez dados às coisas,
as coisas renascidas e os batismos,
as mãos de Beatriz têm novos números
e a fronte nívea é logo nominada.

É já o domínio da poesia pura, do inefável, do encantatório, em que a objetividade do poema épico se dilui, se metamorfoseia na magia mística de uma música e de uma significação que transcende o próprio conhecimento, para se tornar um conhecimento maior, superior, capaz de evocar no leitor profunda e misteriosas vibraçðes estéticas.

Quando empregamos o termo confirmação para estudar também uma nova fase da poesia de Carlos Drummond de Andrade, explicamos que está- 
vamos "enfatizando a significação latina da confirmatio, ou seja, consolidação, afirmaçao, que se confirma, tal como na Igreja, a cerimônia da crisma ou como na retórica a parte da argumentaçao que, segundo Lausberg, demonstra a justeza de nosso próprio ponto-de-vista. Mas ao sair do radical forma, presente nas desıgnaçбes anteriores, estamos tamoém sugerındo a adoçao de uma nova maneira de pensar a poesia". No caso de Jorge de Lima, também se venficam as duas observaç̋es, só que a mudança não for tão marcanıe como se deu com a poesia de Drummond, denors de Liçăo de coisas, coincidentemente livro dos sessenta anos do poeta. Em Jorge de Lima, a modificaçđo se dá em espiral: muda-se no sentido de que o seu novo discurso poético, a partir do Livro de sonetos, procura sintetizar todas as suas experiências poéticas anteriores, com a ressalva de que sintetizar aqui significa também superar, soma e suma, esforço bem logrado de levar à quintessência os temas, as formas e as técnicas acumuladas pela vivência artística (e não somente literária) do poeta. A Poesia recebe aqui o auxílio da Pintura (arte que Jorge de Lima concomitantemente praticou: "Jdi disse e repito: minha pintura, deficiente, imperfeita, autodidata (sic) é tão-somente um complemento de minha poesia"), ${ }^{11}$ da Música, do Cinema, da Literatura (a intertextualidade, estudada por Luiz Busatto) e, claro, das ciências sociais, sobretudo da História luso-brasileira. Desta maneira, Invenção de Orfeu vem a ser nao só o grande livro de Jorge de Lima, mas também o grande coroamento estético de toda a sua poesia. Não é por acaso que coincidiu com o término da vida do poeta: em termos dialético, essa obra que sintetiza e afirma uma outra fase, só poderia ser contestada pela maior de todas as antíteses, que é a morte. Afirmando-se no mais alto da Vida, Invenção de Orfeu terá sempre diante de si a Morte como negação de todo o imaginário. A história da literatura ocidental será a história desse desafio, o qual, no fundo, tem muito a ver com o desafio cultural da própria língua portuguesa.

\subsection{O Sentido das Formas ${ }^{12}$}

A concep̧̧đo poético-retórica de Jorge de Lima na sua Fase de Formaçao está presente nos poemas dos primeiros livros, através de elementos da estrutura retórica, como o seu grande gosto pelos decassflabos, pelos alexandrinos, por todas as formas metrificadas e pela grande atração pelos sonetos, além de elementos da micro-estrutura, como palavras, imagens e ritmos caros à poesia dos parnasianos e simbolistas. E mesmo depois de sua adesão ao modernismo, as novas formas ño perdem a relação estética com a tradição literária. Tanto que, na fase de Transformação, as formas metrificadas 
aparecem misturadas com os versos livres, em poemas isolados e no mesmo poema. E na fase da Confirmação, a de Invenção de Orfeu, há uma verdadeira "festa do intelecto", 13 numa convivência de quase todas as formas métricas. E o mais curioso, dada a liberdade de concepção desse poema, é que não há nele versos livres, fartamente usados nos livros modernistas e nos três grandes livros da fase de Transformação. Assim, do ponto-de-vista puramente formal (no sentido das formas retóricas), Invenção de Orfeu é portanto a sublimaçao dos elementos que o poeta veio exercitando e modificando ao longo de sua trajetória poética. Ou, como numa imagem do canto VIII de Invençāo de Orfeu, "mastigando um só / discurso repetido". Aliás, no canto I, já dizia que "Essa crônica fiel (...)

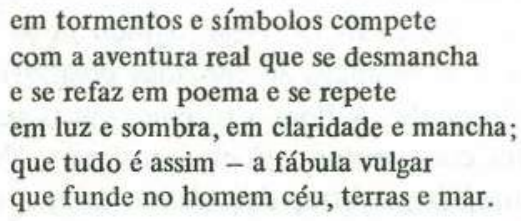

O sentido das formas poéticas de Jorge de Lima é o de que o novo se desenrola de dentro do velho, o moderno sai do tradicional e toda transformação do discurso se dá por dentro da linguagem, revitalizando-se as palavras, as imagens, os versos e os ritmos. Por isso, em Mira-Celi, já se preparando para as aventuras maiores de Invenção de Orfeu, o poeta pôde dizer que "Nunca fui senão uma coisa hibrida/ metade céu, metade terra,/ com a luz de Mira-Celi dentro das duas órbitas", falando logo adiante nos "grandes ciclos poéticos". Em vários momentos de suas várias entrevistas, Jorge de Lima confirma estas observações. Em 1951, diz que "hoje se deve ter em mira também a bela e nobre aventura da forma" (...) "E digo formalismo no sentido autêntico e não pejorativo da expressão". E ainda: "creio em nossa época como sendo de grandes contribuiçōes para a história da poesia, pelo seu retorno à linha clássica e tradicional da arte poética". Numa entrevista de 1945, havia dito: "Fique sabendo desde logo que não tenho parti pris contra isso que vocé chama de 'moldes antigos'. Dentro deles se fez muito boa poesia". Noutra entrevista, já nos fins de 1952, diz que "a poesia se transforma constantemente em sua rota para a eternidade". ${ }^{14}$

\subsection{O tema da Ilha}

A crítica dos temas e de aspectos do plano de conteúdo pøe em evidência as repetiçōes e obsessōes com determinadas palavras e imagens que 
representariam desejos conscientes ou inconscientes. As contribuiçбes da psicanálise ao estudo da literatura podem ser vistas hoje através de duas vertentes: a tradicional, que procura aproveitar as projeções do Autor na obra literária; e uma bem mais atual, de 1970 para cá, que justamente procura eliminar as possíveis codificaçðes do biográfico na obra literária. Um bom exemplo de análises da primeira é a obra de Charles Mauron (Dez métaphores obsédantes au mythe personnel. Introduction a la Psychocritique, L'Inconscient dans l'oeuvre et la vie de Racine, Psychocritique du genre comique e outras), com a teoria de um "mito pessoal" que se projeta na obra, alguma coisa assim como as noçб̃es de psicogênese e sociogênese desenvolvidas por Znedk Pesat. ${ }^{15} \mathrm{~A}$ obra de Jean Starobinski (La rélation critique e Trois fureurs, Essais) serve de exemplo de como se pode fazer psicanálise do texto literário de qualquer época sem ter que conhecer a vida do excritor. Para ele, "o latente está implícito, isto é, é o manifesto - presente no dito e não por trás dele - que não soubemos decifrar na primeira leitura. O latente é uma evidência que espera ser posta em evidência". ${ }^{16}$ Desta forma, o nao-dito do texto não ficou na cabeça do autor: está nas entrelinhas do texto, nos lugares que ño foram privilegiados pela nossa primeira leitura, está naquilo que temos de ligar no próprio texto e, assim, está um pouco na projeção do imaginário do leitor, qualquer que seja ele, mesmo de um leitor que se pretende especializado, como o crítico.

Entre os vários temas, tradicionais ou nđo, na poesia de Jorge de Lima, o de maior recorrência parece o da ilha. A palavra não aparece nos livros da fase de Formaçđo (parnasiano-simbolista). A palavra só começa a aparecer quando o poder de simbolizaçao se manifesta mais fortemente, a partir de Tempo e eternidade, na fase de Transformação, quando a temática religiosa conota aspectos culturais do cristianismo. Daí para frente vai-se tornar a grande constante da sua poesia, culminando com a reiteraçăo fundadora do simbolismo de Invenção de Orfeu.

$\mathrm{Na}$ linha de Starobinski, pode-se ler a palavra ilha primeiramente no seu sentido denotativo, de acidente geográfico, na sua referência histórica à Ilha de Vera e de Santa Cruz, passando-se daí à conotaçбes de ilhas fabulosas, na antiguidade e na época medieval, e às idealizaçбes utópicas dos filósofos renascentistas, até chegar às conotações simbólicas de paraf́so, lugar edênico, chegando-se gradativamente à idéia de "lugar de poesia". E claro que a psicanálise pode levar ainda mais longe essa cadeia analógica, atingindo-se à idéia de vida pré-uterina, de um verdadeiro paraíso perdido da humanidade. Aliás, o título do livro de Jorge de Lima suscita essas correlaçбes, uma vez que nele existem, além de duas realidades que se completam, uma possível ambigüidade de leitura. Temos, de um lado, a "invençశ̃o" - ação que se dá no presente, neste ou no do futuro; e, de outro, "Orfeu" - mito 
que se projeta do passado e acompanha a presentificação da "invenção". Em termos "a invenção de Orfeu" como aquilo que Orfeu inventou, já que Orfeu (ralidade ou mito) foi o inventor da cítara de nove cordas, fato que deve ter contribuído para modificar a concepção poético-musical da época, logo depois de Homero. Mas é também possível ler o sintagma do título como "a invenção da invenção", quando se tomou Orfeu como invenção mitológica. Observe-se de passagem que, tal como se dá com Osíris, Orfeu será estraçalhado pelas mulheres da Trácia e seu corpo repartido, numa alegoria também possível quando se leva em conta a fragmentariedade de Invenção de Orfeu. O Osíris despedaçado pôde ser reunido graças ao olhar amoroso de sua amante e irmá, Isis; o Orfeu, que continha na imaginaçao ocidental e se atualiza no livro de Jorge de Lima, vai precisar do olhar amoroso do leitor que, entretanto, nunca o recomporá, mas apenas o que ele inventou, ou seja, a Poesia.

Do ponto-de-vista puramente simbólico (Cf. Diccionario de los simbolos, de Cirlot), a ilha é "o refúgio contra o ameaçador assalto do mar do inconsciente", é portanto "a síntese da consciência e da vontade". Segundo Cirlot, os hindus concebem a ilha como o ponto de força metafísica, no qual se condensam as forças da imensa ilógica do oceano. Daí ser tida como isolamento, como símbolo do sexo e da poesia. Ora, a ilha em Jorge de Lima, de Tempo e eternidade a Invenção de Orfeu, pode ser lida em todas essas direções e às vezes com citaçбes diretas, como a lenda medieval da ilha de Så Brandao, ilha dos bem-aventurados (As Afortunadas), ilha dourada e redonda, verdadeira imagem do paraíso perdido. É na lenda o lugar de chegada das perigrinações marítimas, tal como vai se dar com a Illha dos Amores, no canto IX de Os Lusiadas. Neste sentido, a imagem de uma ilha utópica e edênica, dourada e redonda, é bem o modelo imaginário global da poesia de Jorge de Lima. Em torno da ilha, tentando expressá-la nas suas mais diversas realidades (geográfica, histórica, filosófica, psicanalítica e poética), ele foi montando, foi superpondo traços desses vários discursos, criando um espaço textual que é a sua ilha, manifestaçao do ser do homem na sua plenitude. A sua ilha é assim o sucedâneo do locus amoenus, lugar onde correm os rios da juventude e da velhice, onde existem as audácias da invenção e o saber silencioso do homem na sua maturidade. É, portanto, conforme já dissemos, o coroamento das transformações formais e técnicas de que o poeta se foi valendo ao longo de seus livros e de sua vida.

O tema da ilha, além de ser uma das isotopias comuns em todos os livros depois de 1935, aparece no título de um poema em Túnica inconsútil e foi também o título de um livro que o poeta publicou nas Ediçøes Hipocampo, no mesmo ano da publicação de Invenção de Orfeu, e que constitui o poema VI do canto IV desse livro. No poema "Convite para a ilha" nos 
diz: "Não digo em que signo se encontra esta ilha/ mas ilha mais bela não há no alto mar". Mas é no seu último livro que a idéia de ilha circular e plural toma vulto para significar talvez uma unidade plural que muito tem a ver com toda a sua poesia. No canto VIII de seu grande poema escreve: "Por essa escala de repetiçōes/ surgem as ilhas dessa anteoceania". No canto X fala que "Há dias essa ilha me envolvia,/ e agora me circunda esse compasso/ giratório, apontando as calmarias". Mas é numa passagem do canto VIII que o poeta faz da ilha o lugar sagrado da poesia e de Deus:

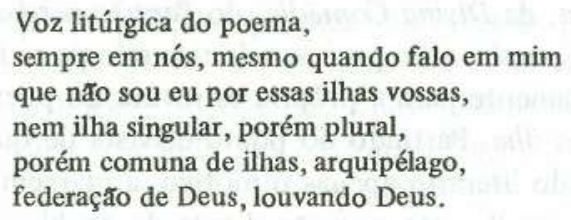

E claro que estas são apenas algumas anotaçбes, destinadas mais a despertar o interesse de alunos para a matéria. Creio que um levantamento exaustivo do tema da ilha, de livro a livro, e o relacionamento dos seus níveis de legibilidade poética constitui uma grande aventura crítica na obra desse grande poeta da língua portuguesa.

\subsection{O Jogo das Técnicas}

A propósito do livro de Luiz Busatto, Montagem: processo de composição em Invençāo de Orfeu, 17 escrevemos o artigo "Os limites da intertextualidade", ${ }^{18}$ mostrando que os processos e técnicas de composição das outras artes, como a colagem da pintura cubista, a polifonia e o simultaneismo da música, a montagem do cinema, bem como as outras invençбes da literatura de vanguarda foram os caminhos abertos pelos escritores, que passaram a chamar a atenção dos críticos para a beleza e o sentido das próprias formas da linguagem. O esforço para superar-se e colocar-se à altura da criação é que fez a crítica produzir novas técnicas de análise e chegar a teoria da intertextualidade, visão que veio revolucionar a concepção do texto literário. Foi preciso que a estilística encontrasse a metodologia semiológica, bem como os diferentes processos de abordagem do texto na atualidade, para que se chegasse ao princípio das diferenças e às margens das várias referências contidas no texto literário. Elas constituem os possíveis da significação do texto e sao motivadas pelo contexto ideológico e pela própria língua, além, é certo, da própria literatura, através dos seus universais, de seus estilos de época e, o que é mais comum, através da forte impressđo causada 
pela leitura de um estilo fortemente individual. Deste modo, inconscientemente, muitos elementos se filtram na produçao literária, tal como, conscientemente, os escritores se aproximam de elementos da tradiçao literária, aceitando as influências, utilizando-as em forma de alusão, de paráfrase, de paródia e de tantos outros recursos do que chamamos "discurso paralelo". Inclusive, o plägio que, para Lautréamont, é necessário, só que aí interferem os valores éticos e jurídicos na defesa da obra plagiada.

Busatto mostra como Jorge de Lima se valeu da técnica da montagem cinematográfica para inserir no seu poema alguns temas, motivos e formas discursivas da Eneida, da Divina Comédia, do Paraiso perdido, de Os Lusiadas e de sua própria poesia, num processo de recorrência e circularidade que nos remete simbolicamente para a própria estrutura do poema, fechado em si mesmo, como uma ilha. Partindo do ponto-de-vista de que "Invençāo de Orfeu pede ao passado literário apcnas o motivo, a margem onde se inscreverá como texto", Luiz Busatto nos póe diante do problema central de sua tese: mostrar a maneira pela qual Jorge de Lima se valeu da tradução que Odorico Mendes fez da Eneida para atingir e requisitar elementos da epopéia de Virgnlio e dar-lhes atualidade no seu poema. Soube ver o texto do poeta alagoano como uma travessia marítima por dentro de várias linguagens do mundo ocidental, uma "viagem escritural" portanto. É nessa viagem que o trabalho de Busatto se empenha em documentar os vários topol da época clássica, como o da Fama, por exemplo.

Se Invenção de Orfeu é o livro onde o jogo das técnicas de apreensão do poético atinge o máximo desempenho e rendimento, o recurso da intertextualidade o poeta o vem usando muito antes do aparecimento do termo, pois já se documenta, como mostramos, desde os seus primeiros livros modernistas, como em "O mundo do menino impossível" e no "Rio de São Francisco", onde se misturảm textos de Euclides da Cunha, Martius, Debret, Saint-Hilaire, além de outros fáceis de serem coligidos. É em Poemas que Jorge de Lima tomou contato direto com as formas simples do folclore nordestino ou das lendas cristas, como a de São Cristóvão, misturando o discurso da lenda com o discurso da história ao montar o título "São Cristóvao Colombo", poema que transcrevemos na fase modernista de sua formaçao. No início o procedimento intertextual é percebido como uma citaç̃o, transcrevendo a referência entre aspas ou em itálico; mais tarde a referência se dá por alusão, indiretamente; e nos últimos livros tudo vira um jogo só de aproximaçб̄es, colisōes e interpenetraçסes que estilhaçam a unidade referencial dos poemas, que apontam ao mesmo tempo para várias direções culturais. Daí a sua pluralidade de sentidos, agarrando-se aqui à raiz germânica (sinnes) que coexistem com o sensus latino na significação geral da palavra sentido nalgumas línguas românicas. A conjugaçđo dessas duas raízes nos 
leva à noção do sentido como o percebido sensorialmente (pelo órgđo e pela sensibilidade) em determinada direçao (a que se toma ao penetrar a obra literária). Uma depende da outra, pois a escolha da direção á comumente ditada pelo ângulo possível da percepção.

\subsection{A Descontínua Unidade}

A divisão da poesia de Jorge de Lima em três fases dialéticas aponta para um todo que tem que ser apreendido através de partes mais facilmente assimiladas. Aponta portanto para uma continuidade que é a marca do tradicional na sua poesia. Só que essa continuidade sofreu também a sua transformação: foi-se tornando descontínua e fragmentária à medida que se ia aperfeiçoando o processo técnico de que se valia o poeta. Uma des/continuidade, porquanto se podem perceber nitidamente na sua poesia a continuidade dos temas e das formas e, ao mesmo tempo, a descontinuidade dos procedimentos na produção da poesia. No fundo, a continuidade de uma Unidade metafísica e poétiça; e mais ou menos superficialmente a descontinuidade dos recursos destinados à apreensao dessa Unidade.

A estrutura de Invenção de Orfeu, tomado agora como síntese e modelo de toda a poesia de Jorge de Lima, recupera a continuidade do discurso épico, com os seus dez cantos mais ou menos encadeados e, através da unidade dos poemas que compõem os cantos, aponta para a descontinuidade da poesia lírica. Essa dualidade entre o épico e o lírico é que faz do seu livro o ponto de encontro de outras dualidades, de outras situaçðes dialéticas da própria vida do escritor, como, por exemplo, a convivência do discurso religioso com a atitude positivista de seus primeiros sonetos. $\mathrm{O}$ conflito se resolvia na poesia: o poeta sintetizava nos seus escritos os conflitos e contradiçбes entre a sua alma profundamente religiosa e o seu pensamento naturalmente positivista. A Arte era a saída da dialética cultural em que se encontrava. Mas a concepção de arte de seu tempo inclinava-se para o sentido científico da Estética, de modo que Religiao e Arte passaram também a oferecer conflito ao poeta. Era preciso portanto uma superaçao do problema. A saída foi levar a Religião à Poesia, isto é, ao poema, mas de tal forma e com tal veemência que a religiao se deixasse ver como a fonte da poesia, a única possível. E assim o poeta que aproximava Nossa Senhora de um artista morto, num soneto dos quinze anos, já pơe num dos XIV alexandrinos a afirmação de que " $O$ Verso é a Arte do Verbo", assim, tudo em maiúscula. E em Mira-Celi irá dizer que "Os grandes poemas comefam com a nossa visão desdobrada/(...)/Subimos em espiral, e em cada volta descrita/nos 
encontramos de novo, frente a frente, mais puros./(...)/O sentido da Trindade Perfeita é para cima, para cima, para cima".

O poeta dirá mais tarde, num dos versos de Invenção de Orfeu, que se filiou "d eternidade sem querer". Ele tem consciência da sua Arte e sabe, como em Octavio Paz, que "a religiao postula uma vida eterna", mas numa eternidade que "despovoa o instante"; acena com uma eternidade depois da vida. A poesia nao: "Entre o nascer e o morrer a poesia nos abre uma possibilidade que ño é a vida eterna das religiōes nem a morte eterna das filosofias, mas um viver que envolve e contém o morrer, um ser isto que é também um ser aquilo". ${ }^{19}$ Um eu que é um outro, que é ele mesmo, dirá o poeta mexicano. Enchendo a sua poesia de religião e fazendo da religiao a força de sua poesia, é possível pensar que Jorge de Lima conquistou de uma vez só a sua dupla eternidade... E ele mesmo o confessou a Alceu Amoroso Lima, que o visitava a menos de um mês da sua morte: "Como vai, Jorge", perguntou-lhe o grande crítico, sem companheiro de geração católica. E a resposta tranqüila do poeta: "Preparado para entrar na Eternidade". E estava mesmo preparado: como poeta e como cristao. ${ }^{20}$

\section{NOTAS}

${ }^{1}$ Conferência na Universidade Federal de ALagoas, no encerramento do I Simpósio de Literatura Alagoana, em 22-4-1883.

${ }^{2}$ O Simpósio sobre literatura alagoana foi em homenagem a Jorge de Lima que em abril completaria noventa anos e terminou homenageando também Alceu Amoroso Lima, dando-lhe o título de Doutor Honoris Causa.

3“"A Transformação da poesia de Drummond", em Letterature d'America no 13, Estate 1982, Bulzoni Editore, Roma.

${ }^{4}$ Utilizamos a Obra completa. Rio de Janeiro, Aquilar, 1958. Volume I, Poesia e Ensaios. O volume II não chegou a ser publicado até agora.

' 5 LEFEBVRE, Henri. Le matérialisme dialectique. Paris, PUF, 1971.

${ }^{6}$ Cf. Montagem em "Inveņ̧ão de Orfeu". Rio de Janeiro, Ãmbito Cultural Ediçđes, 1978.

${ }^{7}$ Cf. meu livro Vanguarda européia e modernismo brasileiro. 7. ed.

${ }^{8}$ ANDRADE, Mário. "A túnica inconsútil" em O Estado de São Paulo, São Paulo, 8.1.1939. 
${ }^{9}$ LIMA, Jorge de. Obra completa, citada.

10 Este parágrafo, bem como os três que se seguem são tirados do nosso livro Camøes e a poesia brasileira. Rio de Janeiro. Livros Técnicos e Científicos, 1979. $3^{\text {a }}$. edição. A 1 a é de 1973.

${ }^{11}$ Cf. "Auto-retrato", na Obra completa, citada.

$12_{\mathrm{Na}}$ impossibilidade de desenvolver por agora as partes $1.2,1.3,1.4 \mathrm{e} 1.5$, o que se segue é apenas transcrição das fíchas que utilizamos no Curso de Pós-Graduação da PUC-RJ e no da UFRJ, no segundo semestre de 1983.

${ }^{13}$ FRIEDRICH, Hugo. Estrutura da lírica moderna. S. Paulo, Suas Cidades.

${ }^{13}$ Essas entrevistas fazem parte do "Auto-retrato intelectual" que acompanha a sua Obra completa. Sđo também importantes os textos "Minhas Memórias"e "Diário", no mesmo volume.

15PESAT, Znedek. "Totalidade da obra e evoluçao da literatura", em Lingütstica formal y critica literaria. Madri, A. Corazón, 1971.

16STAROBINSKI, Jean. La rélation critique. Paris, Minuit, 1972.

${ }^{17}$ Originariamente, tese de Mestrado na PUC-RJ. Citado na nota 6.

${ }^{18} \mathrm{Cf}$. o meu livro A retórica do silêncio. S. Paulo, Cultrix, 1979.

${ }^{19} \mathrm{PAZ}$, Octavio. O arco e a lira. Rio de Janeiro, Nova Fronteira, 1982.

${ }^{20} \mathrm{~A}$ segunda parte deste trabalho (2. A PRESENÇA DE ALCEU AMOROSO LIMA), onde se estuda as relações do crítico com a obra do poeta, não pôde ser preparada para esta publicação.

*Professor de Literatura Brasileira da PUC-RJ, da UFRJ e da UFF. 